\title{
THE
}

1995

\section{Large Scale Isolation of Expression Vector Cassette by Magnetic Triple Helix Affinity Capture}

Srinivas V. Sonti

Matthew C. Griffor

T. Sano

S. Narayanswami

Arijit Bose

University of Rhode Island, bosea@uri.edu

See next page for additional authors

Follow this and additional works at: https://digitalcommons.uri.edu/che_facpubs

Part of the Chemical Engineering Commons

Terms of Use

All rights reserved under copyright.

\section{Citation/Publisher Attribution}

Sonti, S. V. , Griffor, M. C., Sano, T., Narayanswami, S., Bose, A., Cantor, C. R., \& Kausch, A. P. (1995). Large Scale Isolation of Expression Vector Cassette by Magnetic Triple Helix Affinity Capture. Nucleic Acids Research, 23(19), 3995-3996. doi: 10.1093/nar/23.19.3995

Available at: http://www.dx.doi.org/10.1093/nar/23.19.3995

This Article is brought to you for free and open access by the Chemical Engineering at DigitalCommons@URI. It has been accepted for inclusion in Chemical Engineering Faculty Publications by an authorized administrator of DigitalCommons@URI. For more information, please contact digitalcommons-group@uri.edu. 
Authors

Srinivas V. Sonti, Matthew C. Griffor, T. Sano, S. Narayanswami, Arijit Bose, C. R. Cantor, and Albert P. Kausch 


\title{
Large scale isolation of expression vector cassette by magnetic triple helix affinity capture
}

\author{
Srinivas V. Sonti, Matthew C. Griffor ${ }^{3}$, Takeshi Sano', Sandya Narayanswami2, \\ Arijit Bose, Charles R. Cantor ${ }^{1}$ and Albert P. Kausch ${ }^{3, *}$
}

Department of Chemical Engineering, University of Rhode Island, Kingston, RI 02881, USA, ${ }^{1}$ Center for Advanced
Biotechnology, 36 Cummington Street, Boston University, Boston, MA 02215, USA, ${ }^{2}$ The Jackson Laboratory, Main
Street, Bar Harbor, ME 04609, USA and ${ }^{3}$ DeKalb Genetics Corp., 62 Maritime Drive, Mystic, CT 06355-1958, USA

Received August 31, 1995; Accepted September 1, 1995

We have developed a novel procedure for purification of DNA fragments exploiting the specificity of triple helix formation. The preparation of expression vector cassette DNA without extraneous sequences associated with the cloning plasmid has become increasingly more desirable for the production of transgenic organisms. There are a number of protocols for isolating DNA fragments from agarose gels $(1,2)$, although these are cumbersome and time-consuming for the amounts of DNA used for routine transformation procedures $(3,4)$. We present a rapid method for cassette isolation that provides DNA preparations free of contaminating plasmid sequences by constructing DNA expression vectors containing triple helix forming sequences (5) which can be digested from the plasmid and isolated by incubating with biotinylated triple helix forming oligonucleotide followed by magnetic streptavidin separation $(6,7)$. Two plant expression cassettes, p538 (4.61 kb) and p539 (4.61 kb) (Fig. 1), were constructed using the homopurine/ homopyrimidine triple helix forming sequence from pTC45,T-(T-C) 22 (5) and a CaMV 35S/BAR/Tr7 insert from p165(3). The p165 (4.56 kb) and p126 (5.88 kb) plasmids were used as internal controls to establish separation parameters. The p126 plasmid consists of a CaMV 35S/GUS/Tr7 insert in the same plasmid backbone as p165 and also lacks the triple helix forming sequence. An oligonucleotide BTC-20 [5'-biotinylated $(\mathrm{T}-\mathrm{C})_{10}$ ] was synthesized by DNA International.

Figure 2 is a schematic representation of triple helix magnetic affinity capture to isolate insert DNA. The method is based on the formation of a local triple helical structure by specific binding at high $\mathrm{pH}$ of homopyrimidine oligonucleotides in the major groove of duplex DNA parallel to the purine Watson-Crick strand through the formation of Hoogsteen hydrogen bonds (5). Triple helix formation is highly specific to thymine recognition of adenine-thymine (A.T) base pairs and protonated cytosine $\left(\mathrm{C}^{+}\right)$ recognition of guanine-cytosine $(\mathrm{G} \cdot \mathrm{C})$ base pairs $\left(\mathrm{C}^{+}-\mathrm{GC}\right.$ triplets) which is reversible when the $\mathrm{pH}$ is lowered $(6,7)$. First, to evaluate separation conditions, undigested mixtures $(1: 1)$ consisting of circular and supercoiled forms of triple helix forming plasmids, p538 and p539, and control plasmids, p165 and p126, were tested for isolation with BTC-20 and magnetic beads obtained from Perseptive Biosystems. Plasmid DNA

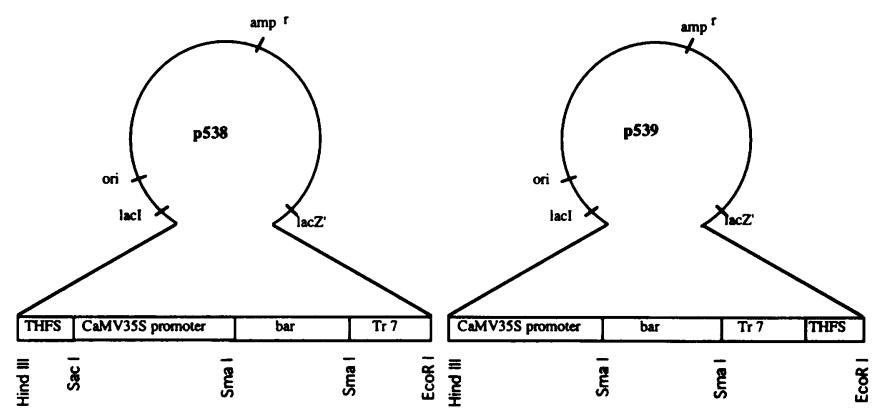

Figure 1. Plant expression vectors containing triple helix forming sequence (THFS).

$(\sim 2 \mu \mathrm{g})$ was incubated with 10 pmol BTC-20 in $90 \mu$ l buffer B $(2.0 \mathrm{M} \mathrm{NaCl}, 0.2 \mathrm{M}$ sodium acetate/acetic acid, $\mathrm{pH} 4.5-5.5)$ at $50^{\circ} \mathrm{C}$ for 2 h. Streptavidin coated magnetic beads $(50 \mu \mathrm{l})$, concentrated to $10 \mu \mathrm{l}$ and resuspended in buffer $\mathrm{B}$, were added to the mixture and further incubated for $30 \mathrm{~min}$ at $25^{\circ} \mathrm{C}$. Subsequently, the beads were separated in an internal field magnetic particle concentrator and washed three times with $300 \mu \mathrm{l}$ buffer B. Finally, the beads were incubated with buffer E $(1.0 \mathrm{M}$ Tris- $\mathrm{HCl} \mathrm{pH} \mathrm{9,} 0.5 \mathrm{mM}$ EDTA) for $45 \mathrm{~min}$ and isolated using the magnetic separator. Isolated DNA was recovered from the eluate (Fig. 3). As shown, recovery of undigested plasmids containing triple helix forming sequences from contaminating plasmid DNA is specific and nearly complete (Fig. 3A). This indicates that there is minimal non-specific binding of the magnetic beads to either of the control plasmids. None of the lanes in row 2 contain either p126 or p165. However, lanes 2 and 4 contain p538, and lanes 3 and 5 contain p539 where recovery is estimated to be $>80 \%$. In repeated experiments, the recovery has varied from 60 to $95 \%$, depending on streptavidin preparations.

Samples of p538 and p539 plasmid DNA were then digested with HindIII and EcoRI to release the insert. The efficiency of insert isolation from plasmid DNA of p538 (Fig. 3B) was determined with the same procedure as described above. Lanes 1 and 2 show the backbone of p538 remaining after the insert DNA

\footnotetext{
${ }^{*}$ To whom correspondence should be addressed
} 


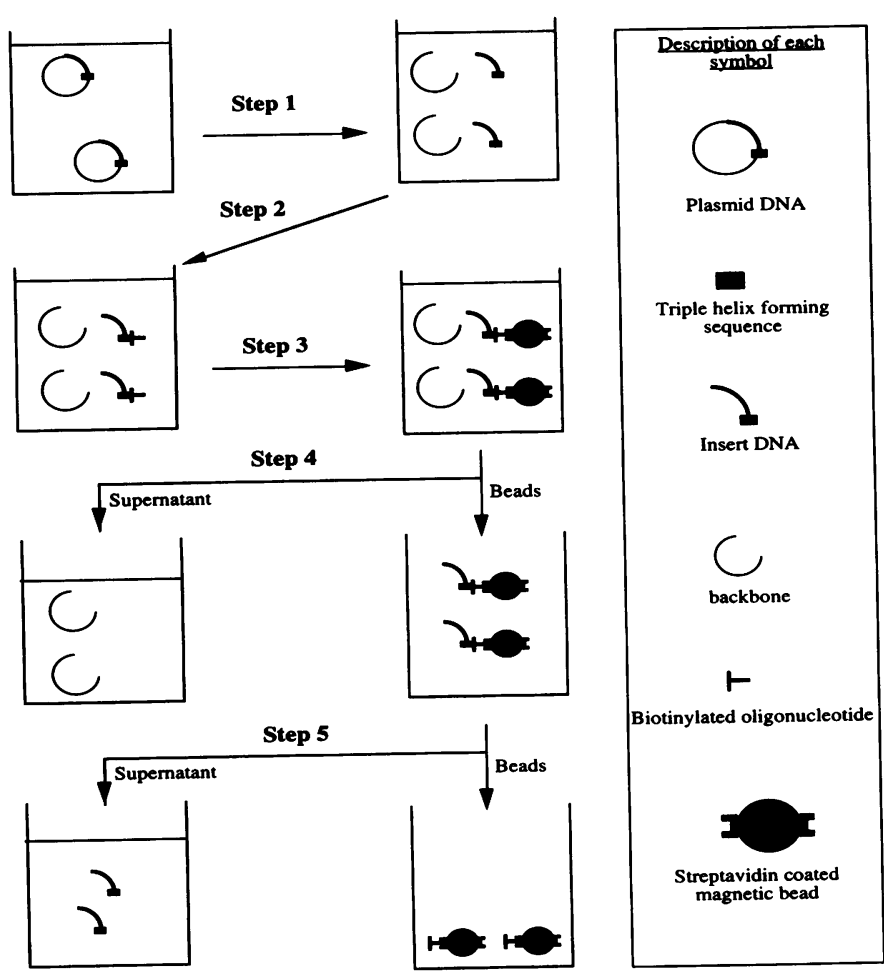

Figure 2. Schematic illustration of triple helix affinity capture procedure. Digested plasmid containing a triple helix forming sequence is incubated with a biotinylated oligonucleotide forming a triple helix at slightly acidic $\mathrm{pH}$. The triple helix is captured by interaction of the biotin moiety with a streptavidin magnetic particle, magnetically separated and washed. Elution of the expression cassette containing the triple helix is performed at alkaline $\mathrm{pH}$. Step 1, plasmid is digested with restriction endonuclease; step 2, biotinylated oligonucleotide is added at pH 5; step 3, streptavidin coated magnetic beads are added; step 4, Magnetic separation; step 5, elution of bound DNA with a mild alkaline buffer ( $\mathrm{pH} 9.0)$.

was isolated by triple helix affinity capture. The extraction of the insert DNA is estimated to be $>95 \%$. Lanes 3 and 4 show the isolated insert with purity close to $100 \%$. Lanes 1 and 3 show results obtained using Bioquest beads, lanes 2 and 4 are similar results using beads from Perseptive Biosystems. Recovery of insert DNA was reduced with beads that were more than two months old. Stability of the magnetic particles might be a parameter influencing the efficacy of separation (8). In order to obtain insert DNA in bulk quantities suitable for cell transformation experiments a scale up of the above procedure was tested. Digested plasmid DNAs p538 and p539 (100 $\mu \mathrm{g}$ each) were incubated with $0.5 \mathrm{nmol}$ BTC-20 in $4.5 \mathrm{ml}$ of buffer B at $50^{\circ} \mathrm{C}$ for $2 \mathrm{~h}$. A $2.5 \mathrm{ml}$ aliquot of streptavidin-coated magnetic beads was concentrated to $0.5 \mathrm{ml}$ and resuspended in buffer $\mathrm{B}$, and added to the mixture. This suspension was further incubated for $30 \mathrm{~min}$ at $25^{\circ} \mathrm{C}$. Subsequently, the beads were separated by using a hand held rare earth magnet and washed three times with $5 \mathrm{ml}$ buffer B. Finally, the beads were incubated with buffer E for $45 \mathrm{~min}$ and isolated using the magnet. Insert DNA was recovered from the eluate. During this entire procedure the beads were kept in suspension by intermittent shaking. In Figure 3C, lanes 1 and 2 are the supernatants of p538 and p539 respectively; lanes 3 and 4 are the eluates corresponding to lanes 1 and 2; lane 5 is a p538 control which was not subjected to magnetic separation. A
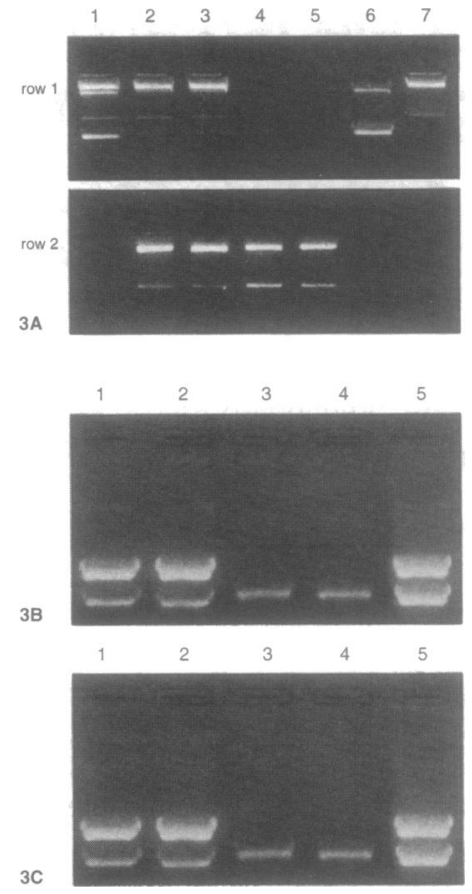

Figure 3. Gel electrophoresis of isolated triple helix products. (A) Comparative recovery of undigested plasmids from contaminating DNA in supernatant (row 1) and eluant (row 2). Row 1: lane 1 is a mixture of p126 and p165; lane 2 is a mixture of p538 and p126; lane 3 is a mixture of p539 and p126; lane 4, p538; lane 5, p539; lane 6, p165; lane 7, p126. Row 2: lane 1, blank lane 2 is p538; lane 3, p539; lane 4, p538; lane 5, p539, lanes 6 and 7, blank. (B) Cassette isolation from digested p538; lanes 1 and 2, supernatant; lanes 3 and 4, eluted cassette; lane 5, unseparated control. (C) Large scale cassette isolation from digested p538 and p539 (respectively); lanes 1 and 2, supernatant; lanes 3 and 4 , eluted cassette; lane 5, unseparated p538 control.

comparison of the intensities of the bands in lanes 1 and 2 with 3 and 4 , as well as with the band in lane 5, indicates recovery and purity of insert DNA to be 55 and $100 \%$, respectively. We were able to recover $>90 \%$ of the insert DNA with freshly prepared components. In Figure 3C, Bioquest beads were used to isolate inserts from p538 and Perseptive beads were used to isolate inserts from $\mathrm{p} 539$.

\section{ACKNOWLEDGEMENTS}

Streptavidin coated magnetic beads were generous gift from Perseptive Biosystems, Cambridge MA (product \#8-4660A) and Bioquest Inc., Atkinson NH (product \#0100-0601-P19). Internal Field Magnetic Particle Concentrator was a generous gift from Immunicon Inc.

\section{REFERENCES}

1 Wang,Z., Rossman,T.G. (1994) Nucleic Acids Res., 22, 2862-2863.

2 Pun,K.K., Kam,W. (1990) Preparative Biochemistry, 20, 123-125.

3 Gordon-Kamm W. J., et al. (1990) Plant Cell, 2, 603-618.

4 Laursen,C.M.,et al. (1994) Plant Mol. Biol., 24, 51-61.

5 Ito,T., Smith,C.L., Cantor,C.R. (1992) Proc. Natl. Acad. Sci. USA, 89, 495-498.

6 Ji,H., Smith,L.M. (1993) Anal. Chem., 65, 1323-1328.

7 Ji,H., Smith,L.M., Guilfoyle (1994) GATA, 11(2), 43-47.

8 Sano, T., et al. Advances Biomagnetic Separations, Eaton Publishing Co., Natick, MA 